\title{
PEMAHAMAN KONSEP DAN PENALARAN MATEMATIKA SISWA DALAM PEMBELAJARAN MATRIKS
}

\author{
Munasiah $^{1}$, Ai Solihah ${ }^{2}$, Heriyati $^{3}$ \\ Program StudiInformatika, Universitas Indraprasta PGRI Jakarta ${ }^{1,2,3}$ \\ Email: munasiahunindra@gmail.com
}

\begin{abstract}
Abstrak
Tujuan dari penelitian ini yaitu mengetahui hubungan serta pengaruh pemahaman konsep matematika dengan penalaran matematika dalam pembelajaranmatriks SMA kelas XI. Pada penelitian ini digunakan metode survei, pengambilan sampel secara random. Skor didapatkan dari tes pemahaman dan penalaran matematika sebanyak 54 siswa. Berdasarkan perhitungan SPSS 20. Nilai koefisien korelasi antara pemahaman konsep matematika dengan penalaran matematika sebesar 0,695, artinya hubungan kuat. Nilai signifikansinya $0,000<0,005$ yang berarti signifikan. Persamaan regresinya adalah $\hat{Y}=-0,989+9,71$, jika pemahaman konsep tidak ada maka penalaran matematika bernilai negatif. Nilai koefisien regresi $X$ sebesar 9,71 menyatakan bahwa setiap penambahan satu nilai untuk pemahaman konsep matematika akan menambah penalaran matematika sebesar 9,71. Dari data dan analisa di atas,menunjukkan bahwa terdapat hubungan yang signifikan antara pemahaman konsep dengan penalaran matematika siswa pada materi matriks, ditunjukkan dengan nilai koefisien korelasi sebesar 0,695 yang berarti hubungan kuat, sig. $0,000<0,005$ artinya signifikan.
\end{abstract}

Kata Kunci : pemahaman konsep, penalaran, matematika

\begin{abstract}
The purpose of this study is to determine the relationship and influence of understanding mathematical concepts with mathematical reasoning in learning matrix on grade XI of senior high school. In this study the survey method was conducted using random sampling. The scores were obtained from the 54 students' understanding and mathematical reasoning tests. Based on SPSS calculations 20. Correlation coefficient between the understanding of mathematical concepts with mathematical reasoning is 0.695 , meaning a strong relationship. The significance value is 0,000 $<0,005$ which means that it is significant. The regression equation is $\hat{Y}=-0,989+9,71$, if there is no concept understanding then mathematical reasoning is negative. The regression coefficient $X$ value of 9.71 states that each addition of one value to the understanding of mathematical concepts will increase mathematical reasoning by 9.71. From the data and analysis above, it is shown that there is a significant relationship between understanding concepts and students' mathematical reasoning on the matrix material, indicated by the correlation coefficient of 0.695, which means a strong relationship, sig. 0,000<0.005 that means significant.
\end{abstract}

Key Words : Concept understanding, reasoning, mathematics

\section{PENDAHULUAN}

Pendidikan merupakan salah satu aspek dalam kehidupan yang memegang peranan penting. Suatu negara dapat mencapai sebuah kemajuan dalam teknologinya, jika pendidikan dalam negara berkualiatas baik. Tinggi rendahnya kualitas pendidikan, baik pendidikan formal maupun nonformal dalam suatu negara dipengaruhi oleh banyak faktor. Faktor yang mempengaruhi pendidikan formal yang berada di sekolah bisa berasal dari peserta didik, tenaga pendidik, sarana prasarana, dan bisa juga karena faktor lingkungan. Melalui Sekolah, berbagai macam hal dipelajari oleh peserta didik. Dalam pendidikan formal, belajar memperlihatkan perubahan yang positif, diharapkan pada tahap akhir didapatkan keterampilan, kecakapan, dan pengetahuan baru.

Faktor yang mempengaruhi belajar siswa baik pada pendidikan formal maupun non formal bisa berasal dari faktor intern dan 
faktor ekstern. Faktor intern adalah faktor yang ada dalam individu yang sedang belajar yaitu faktor jasmani (kesehatan, cacat tubuh), faktor psikologis (intelegensi, perhatian, minat, bakat, motif, kematangan, kesiapan dan lain sebagainya), dan faktor kelelahan siswa. Faktor ekstern adalah faktor yang ada diluar individu yaitu faktor keluarga (cara orang tua mendidik, suasana rumah, keadaan ekonomi keluarga, pengertian orang tua dan lain-lain), faktor sekolah (metode mengajar, kurikulum, relasi guru dengan siswa, disiplin sekolah, sarana dan prasarana dan sebagainya), faktor masyarakat (kegiatan siswa dalam masyarakat, mass media, teman bergaul, bentuk kehidupan masyarakat dan lainlain).

Matematika berperan penting dalam berbagai disiplin ilmu pengetahuan, baik dalam bidang sosial, ekonomi, maupun sains. Kemampuan matematika pada seseorang dapat membentuk orang tersebut berpola pikir sistematis, mampu bernalar, menduga, menyimpulkan, rasa ingin tahu yang besar, serta kreatif [1].

Penalaran adalah suatu proses berpikir dalam menentukan kesimpulanatau membuat pernyataan dari pernyataan sebelumnya dan kebenarannya telah dibuktikan [2]. Penalaran merupakan suatu kegiatan berpikir yang memiliki ciri-ciri tertentu. Ciri yang pertama logika yaitu adanya suatu pola berpikir yang secara luas, ciri yang kedua yaitu sifat analitik dari proses berpikirnya, kegiatan berpikir berdasarkan langkah-langkah tertentu. Penalaran merupakan keterampilan berpikir yang dapat ditingkatkan melalui latihan secara berulang-ulang [3].

Kemampuan penalaran adalah kemampuan siswa dalam menarik kesimpulan berdasarkan fakta dan sumber yang ada [4]. Kemampuan penalaran yang baik pada siswa terlihat pada kemampuan berpikir secara logis, baik yang bersifat deduktif maupun induktif. Sebagai contoh dalam menyelesaikan soalpada materi matriks siswa mampu menyatakan kembali konsep-konsep yang menjadi dasar atas penyelesaian soal. Selain itu, siswa mampu berpikir analitik, yaitu suatu kegiatan berpikir berdasarkan langkah-langkah tertentu. Siswa mampu membuktikan teorema tertentu serta mampu menentukan kesimpulan berdasarkan langkah-langkah yang benar, misalnya dengan induksi matematik. Kemampuan penalaran tinggi siswa ditunjukkan pada kemampuannya menghubungkan benda nyata, gambar maupun soal-soal cerita ke dalam ide matematika dan menjelaskan kembali ide matematika tersebut dengan lisan maupun tulisan. Untuk melatih kemampuan penalaran siswa dapat dibiasakan untuk memecahkan masalah-masalah matematika [3].

Keabstrakan matematika salah satu faktor yang membuat matematika terasa sulit untuk siswa. Siswa sulit untuk membayangkan apa yang sedang mereka pelajari, kebanyakan dari mereka hanya menghafalkan rumusnya bukan memahami konsepnya. Oleh karena itu, agar siswa dapat memahami materi pelajaran matematika khususnya materi matriks, siswa perlu ditekankan pada pemahaman konsep.

Salah satu tujuan pembelajaran matematika yang diharapkan adalah kemampuan memahami konsep matematika. Siswa yang pemahaman konsepnya bagus akan lebih mengetahui ide-ide matematika yang tersembunyi [5].

Pemahaman konsep adalah kemampuan siswa untuk mengungkapkan kembali materi pelajaran dalam bentuk yang mudah dimengerti dan mampu mengaplikasikan konsep yang sesuai dengan struktur kognitif yang dimilikinya 
[6]. Pemahaman konsep dibedakan menjadi dua, yaitu pemahaman instrumental dan pemahaman relasional. Pemahaman instrumental adalah pemahaman atas konsep yang terpisah dan hanya sekedar hafal rumus sederhana saja. Pemahaman relasional merupakan pemahaman yang memuat skema dan struktur yang dapat digunakan untuk menyelesaikan masalah yang lebih luas dan berarti.

Selama ini pembelajaran matematika disampaikan hanya melalui ceramah/ekspositori, bacaan, meniru, melihat, mengganti, dan sebagainya bukan diperoleh melalui penemuan [7].

Pemahaman konsep matematika siswa yaitu ketika siswa mengerti sesuatu, mereka dapat menjelaskan konsep-konsep dalam kalimat mereka sendiri, menggunakan informasi dengan tepat dalam konteks baru, membuat analogi baru, dan generalisasi. Pemahaman konsep merupakan dasar dari pemahaman prinsip dan teori teori, sehingga untuk memahami prinsip dan teori terlebih dahulu siswa harus memahami konsep-konsep yang menyusun prinsip dan teori tersebut. Karena itu hal yang sangat fatal apabila siswa tidak memahami konsep-konsep matematika, jika mereka ingin menguasai matematika khususnya kemampuan berpikir tingkat tinggi siswa antara lain penalaran matematika. Kemampuan penalaran matematika yang rendah akan berpengaruh pada kualitas belajar siswa, yang berakibat pula pada rendahnya hasil belajar siswa di sekolah [4].

Dari uraian di atas, peneliti merasa tertarik untuk meneliti seberapa kuat hubungan antara pemahaman konsep dengan penalaran matematika, serta ingin mengetahui seberapa besar pengaruh dan nilai korelasinya. Dari hasil penelitian ini diharapkan guru dapat lebih menekankan pemahaman konsep dalam pembelajaran matematika sehingga penalaran matematika siswa juga semakin tinggi.

\section{METODE}

Penelitian ini dilaksanakan pada bulan November 2019 di SMA IT Tunas Bangsa Depok, menggunakan metode survey dengan pendekatan kuantitatif, dimana peneliti menggambarkan fenomena yang terjadi berdasarkan data yang diambil dari responden menggunakan instrumen yang telah divalidasi sebelumnya. Instrumen berbentuk tes dari variabel pemahaman konsep dan penalaran. Desain penelitian yang digunakan dalam penelitian ini adalah desain penelitian korelasional variabel bebas $(X)$ dalam penelitian ini adalah pemahaman konsep matematika siswa, sedangkan variabel terikat $(Y)$ adalah penalaran matematika siswa.

Teknik analisis yang digunakan yaitu menggunakan teknik analisis korelasi pearson product moment. Koefisien korelasi yang dihasilkan mengindikasikan hubungan antara pemahaman konsep matematika siswa dengan penalaran matematika siswa. Populasi target pada penelitian ini adalah seluruh siswa SMAIT Tunas Bangsa kelas XI tahun ajaran 2019/2020, sampel diambil sebanyak 54 orang siswa dari dua kelas.

\section{HASIL DAN PEMBAHASAN}

Dalam deskripsi data penelitian ini akan dikemukakan berbagai hasil penelitian dari data yang diperoleh, yang meliputi: skor tertinggi, skor terendah, rerata (mean), modus, median, ragam/varians dan simpangan baku/standar deviasi. Dalam pengolahan data yang diperoleh, peneliti melakukan pengolahan data dengan bantuan Microsoft Office Excel 2007 dan SPSS 20 dengan hasil sebagai berikut : 
Tabel 1. Deskripsi Data Penelitian

\begin{tabular}{|c|c|c|c|}
\hline \multicolumn{4}{|c|}{ Statistics } \\
\hline \multirow{2}{*}{$N$} & Valid & 54 & 54 \\
\hline & Missing & 0 & 0 \\
\hline \multicolumn{2}{|c|}{ Mean } & 12,28 & 13,67 \\
\hline \multicolumn{2}{|c|}{ Std. Error of Mean } & ,665 & ,477 \\
\hline \multicolumn{2}{|c|}{ Median } & 13,00 & 14,00 \\
\hline \multicolumn{2}{|c|}{ Mode } & $10^{\mathrm{a}}$ & 12 \\
\hline \multicolumn{2}{|c|}{ Std. Deviation } & 4,889 & 3,502 \\
\hline \multicolumn{2}{|c|}{ Variance } & 23,903 & 12,264 \\
\hline \multicolumn{2}{|c|}{ Skewness } &,- 140 &,- 403 \\
\hline \multicolumn{2}{|c|}{ Std. Error of Skewness } & ,325 &, 325 \\
\hline \multicolumn{2}{|c|}{ Kurtosis } & $-1,198$ &,- 212 \\
\hline \multicolumn{2}{|c|}{ Std. Error of Kurtosis } & ,639 & 639 \\
\hline \multicolumn{2}{|c|}{ Range } & 17 & 15 \\
\hline \multicolumn{2}{|c|}{ Minimum } & 3 & 5 \\
\hline \multicolumn{2}{|c|}{ Maximum } & 20 & 20 \\
\hline \multicolumn{2}{|c|}{ Sum } & 663 & 738 \\
\hline \multicolumn{4}{|c|}{ a. Multiple modes exist. The smallest value is shown } \\
\hline
\end{tabular}

Pengujian Asumsi Linier Klasik Uji Normalitas
Berdasarkan uji normalitas, didapatkan hasil sebagai berikut.

Tabel 2. Output Uji Normalitas SPSS 20.

\begin{tabular}{lll}
\hline \multicolumn{3}{c}{ One-Sample Kolmogorov-Smirnov Test } \\
& & Unstandardized Residual \\
\hline$N$ & Mean & .0000000 \\
Normal & Std. Deviation & 3.51352629 \\
Parameters $^{a, b}$ & Stolute & .067 \\
Most & Absolive & .067 \\
Extreme & Positive & -.061 \\
Differences & Negative & .494 \\
Kolmogorov-Smirnov Z & .968 \\
Asymp. Sig. (2-tailed) & \\
\hline a. Test distribution is Normal. & \\
b. Calculated from data. &
\end{tabular}

Dari hasil output SPSS tersebut menunjukkan bahwa nilai signifikansi Aasymp. Sig. (2-tailed) sebesar 0,968 lebih besar dari 0,05, maka sesuai dengan pengambilan keputusan dalam uji normalitas kolmogorov-smirnov, dapat disimpulkan bahwa data berdistribusi normal. Dengan demikian, asumsi atau persyaratan normalitas dalam model regresi sudah terpenuhi.

\section{Uji Linieritas}

Secara umum uji linieritas bertujuan untuk mengetahui apakah dua variabel memiliki hubungan yang linier secara signifikan atau tidak. Korelasi yang baik seharusnya terdapat hubungan yang linier antara variabel bebas dan variabel terikat. Berikut hasil uji linier dari pemahaman konsep matematika dan penalaran matematika. 
Tabel 3. Hasil Uji Linieritas SPSS 20.

\begin{tabular}{lcc}
\hline & \multicolumn{2}{c}{ Penalaran Matematika } \\
& $\boldsymbol{F}$ & Sig. \\
\hline Pemahaman & & \\
Konsep & 1,975 & 0,057 \\
\hline
\end{tabular}

Tabel di atas menunjukkan bahwa nilai Deviation from Linearity Sig. 0,057 lebih besar dari 0,05, maka dapat disimpulkan bahwa ada hubungan linier secara signifikan antara variabel pemahaman konsep matematika dengan penalaran matematika.

\section{Uji Heterokedastisitas}

Dalam penelitian ini cara mengetahui ada tidaknya gejala heterokedastisitas dalam regresi menggunakan uji glejser. Prinsip kerja uji heterokedastisitas menggunakan uji glejser ini adalah dengan cara meregresikan variabel independent terhadap nilai absolute residual (Abs_RES). Berikut hasil output dari perhitumgan uji heterokedastisitas:

\section{Tabel 4. Hasil uji heterokedastisitas} SPSS 20.

\begin{tabular}{lccc}
\hline & & Penalaran & Matematika \\
& & $\boldsymbol{t}$ & Sig. \\
\hline $\begin{array}{l}\text { Pemahaman } \\
\text { matematika }\end{array}$ & 1,070 & 0,289 \\
\hline
\end{tabular}

Berdasarkan output di atas, diketahui nilai Sig. untuk pemahaman konsep matematika adalah 0,289 lebih besar dari 0,05 artinya tidak terjadi gejala heterokedastisitas dalam model regresi. Uji asumsi klasik terpenuhi maka perhitungan dapat dilanjutkan menggunakan analisis korelasi.

Analisis korelasi dengan menggunakan uji koefisien korelasi dimaksud untuk mengetahui derajat hubungan antara variabel $X$ (pemahaman konsep matematika) dengan variabel $Y$ (penalaran matematika). Hasil analisis korelasi berdasarkan perhitungan SPSS 20. Sebesar 0,695 yang berarti terdapat hubungan yang kuat antara pemahaman konsep matematika $(X)$ dengan penalaran matematika (Y). Nilai Sig.(2-tailed) antara pemahaman konsep matematika $(X)$ dengan penalaran matematika $(Y)$ adalah sebesar $0,000<0,05$, yang berarti terdapat korelasi yang signifikan antara variabel $X$ dengan variabel $Y$. Nilai koefisien determinasi yang diperoleh dari SPSS 20 sebesar 0,484. Hal ini menunjukkan bahwa besarnya koefisien determinasi 48,4\% artinya $51,2 \%$ dipengaruhi oleh varibel selain variabel pemahaman konsep matematika.

Untuk mengetahui ada tidaknya hubungan antara variabel $X$ (pemahaman konsep) dengan variabel $Y$ (penalaran matematika) penulis menggunakan teknik analisis korelasi pearson product moment. Untuk perhitungan menggunakan SPSS 20. kooefisien korelasi sebesar 0,695 dengan signifikansi 0,000 . Nilai signifikansi 0,000 $<0,05$ maka terdapat hubungan yang signifikan antara pemahaman konsep matematika dengan penalaran matematika.

Berdasarkan hasil koefisien korelasi dapat dilihat korelasi bersifat positif yang artinya semakin tinggi pemahaman konsep matematika, maka semakin tinggi penalaran matematika. Hasil penelitian ini menunjukkan pentingnya pemahaman konsep matematika sebagai pondasi dalam memahami materi yang lebih tinggi, hal ini sejalan dengan penelitian yang menyimpulkan bahwa pengajaran matematika harus mengarah pada penguasaan konsep matematika siswa [8].

Pemahaman konsep yang baik menunjang baiknya penalaran matematika, pembelajaran yang berfokus pada penalaran membutuhkan konsep tahapan yang lebih rendah, senada dengan penelitian yang menyebutkan bahwa kemampuan penalaran matematis siswa tidak ada tanpa kemampuan pemahaman yang baik [9]. 


\section{SIMPULAN}

Berdasarkan hasil analisa data dan pembahasan dari penelitian ini, maka dapat disimpulkan: (1) Ada hubungan yang signifikan antara pemahaman konsep dengan penalaran matematika pada materi matriks. (2) Hubungan antara pemahaman konsep matematika dengan penalaran matematika, adalah kuat sebesar 0,695 dengan signifikansi 0,000 .

\section{DAFTAR PUSTAKA}

[1] A. Wibowo. "Pengaruh Pendekatan Pembelajaran Matematika Realistik dan Saintifik terhadap Prestasi Belajar, Kemampuan Penalaran Matematis dan Minat Belajar". $J$. Ris. Pendidik. Mat., vol. 4, no. 1-10, pp. 1, 2017.

[2] T. S. Sumartini. "Peningkatan Kemampuan Pemecahan Masalah Matematis Siswa melalui Pembelajaran Berbasis Masalah". Mosharafa J. Pendidik. Mat., vol. 5, no. 2, pp. 148-158, 2018.

[3] Sukayasa. "Penalaran dan Pemecahan Masalah dalam Pembelajaran Geometri”. Pros. Semin. Nas. Penelitian, Pendidik. dan Penerapan MIPA Fak. MIPA, Univ. Negeri Yogyakarta, pp. 545552, 2009.

[4] F. M. Putri. "Pengaruh Pembelajaran Matematika Realistik terhadap Kemampuan Penalaran Matematis Siswa SMP". J. Edumatica, vol. 3, no. 1, pp. 19-26, 2013.

[5] I. Masitoh dan S. Prabawanto. "Peningkatan Pemahaman Konsep Matematika dan Kemampuan Berfikir Kritis Matematis Siswa Kelas V Sekolah Dasar Melalui Pembelajaran Eksloratif". EduHumaniora | J. Pendidik. Dasar Kampus Cibiru, vol. 7, no. 2, pp. 186-197, 2016.

[6] S. Hadi dan M. Umi Kasum. "Pemahaman Konsep Matematika Siswa SMP Melalui Penerapan Model Pembelajaran Kooperatif Tipe Memeriksa Berpasangan (Pair Checks)". EDU-MAT J. Pendidik. Mat., vol. 3, no. 1, pp. 59-66, 2015.

[7] D. P. Wulandari. "Meningkatkan Pemahaman Konsep Matematika Siswa SD Melalui Pembelajaran dengan Pendekatan Problem Posing". EduHumaniora | J. Pendidik. Dasar Kampus Cibiru, vol. 7, no. 2, pp. 131-139, 2016.

[8] L. Novitasari dan Leonard. "Pengaruh Kemampuan Pemahaman Konsep Matematika terhadap Hasil Belajar Matematika". in Prosiding Diskusi Panel Nasional Pendidikan Matematika, pp. 539-548, 2017.

[9] R. Fuadi, R. Johar, dan S. Munzir. "Peningkatkan Kemampuan Pemahaman dan Penalaran Matematis Melalui Pendekatan Kontekstual". vol. 3, no. 1, pp. 4754, 2016. 